\title{
MRSA: the leading pathogen of orthopedic infection in a tertiary care hospital, South India
}

\author{
Thimmappa Latha ${ }^{1}$, Bhat Anil ${ }^{2}$, Hande Manjunatha ${ }^{2}$, Mukhopadhyay Chiranjay ${ }^{2}$, \\ Devi Elsa ${ }^{1}$, Nayak Baby ${ }^{1}$, George Anice ${ }^{1}$
}

1. Manipal College of Nursing Manipal, Manipal Academy of Higher Education Manipal.

2. Kasturba Medical College Manipal, Manipal Academy of Higher Education Manipal.

\begin{abstract}
Background: The rate of infection is high and heterogeneous in developing countries. This study aimed to find the rate and pattern of infection in a tertiary care hospital with a goal to improve the infection control practices.

Methods: The study was conducted in the orthopedic units of a multispecialty teaching hospital. Medical records of major orthopedic surgery adult patients without immunosuppression state were included. The bacterial culture report of the wound swabs were noted over a period of one year. The bacterial culture testing was performed by a recommended method.

Results: Among 2,249 orthopedic surgery patients, $83.7 \%$ were males, $49.1 \%$ had open wounds during admission and $32.2 \%$ patients were infected. Majority $(64.2 \%)$ of the injuries were in the lower limb with $19.4 \%$ patients having undergone multiple surgeries during hospitalization. A total of 946 pathogens were grown from 725 specimens. Staphylococcus aureus was the maximum (48.4\%) followed by Pseudomonas aeruginosa (26.3\%) and E coli (16.7\%). Among them, 57.3\% were Methicillin Resistant Staphylococcus aureus (MRSA) and was the leading pathogen causing infection among orthopedic patients.

Conclusion: MRSA infection was high. Consequent to this, an interventional program entitled 'Extended Infection Control Measures' was designed to reduce the burden of infection.

Keywords: MRSA, orthopedic, infection, South India.

DOI: https://dx.doi.org/10.4314/ahs.v19i1.12

Cite as: Latha T, Anil B, Manjunatha H, Chiranjay M, Elsa D, Baby N, et al. MRS A: the leading pathogen of orthopedic infection in a tertiary care hospital, South India. Afri Health Sci. 2019;19(1). 1393-1401. bttps:// dx.doi.org/10.4314/ahs.v19i1.12
\end{abstract}

\section{Introduction}

Health care associated infection is an important unwanted event in health care delivery system which accounts for $7 / 100$ infection in the developed countries and 10/100 in the developing countries ${ }^{1}$. Global Antibiotic Resistance Partnership (GARP) - India working group and Centre for Disease Dynamics, Economics and Policy (CDDEP) have reported that the hospital incidence of acquired infection in India is relatively high. The rate of Vancomycin

\section{Corresponding author:}

Bhat Anil, Kasturba Medical College Manipal, Manipal Academy of Higher Education Manipal.

Email: anilkbhat@yahoo.com resistant Enterococcus and Methicillin Resistant Staphylococcus aureus (MRSA) infections have significantly increased in India ${ }^{2}$. Staphylococcus aureus, coagulase negative Staphylococcus, E coli, Klebsiella pneumoniae, Enterobacter species, Citrobacter species, Pseudomonas aeruginosa are the frequently noted pathogens causing infection in the hospital ${ }^{3-5}$. These micro-organisms are commonly prevalent in the air, contaminated food and water, medication, equipment, soiled linen, hospital waste and contaminated wounds ${ }^{5}$. Patient's flora, cross-infection from other patients and health care personnel also contribute to the source of infection ${ }^{5}$. Open fractures, crush injuries, chronic osteomyelitis, chronic ulcers, instrumentation, arthrotomies, amputation and implants cause a variety of infection among orthopedic patients ${ }^{3,5,6}$. However, the rate of orthopedic infection is not homogenous ${ }^{4,5}$.

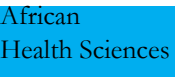

(C) 2019 Latha et al. Licensee African Health Sciences. This is an Open Access article distributed under the terms of the Creative commons Attribution License (https://creativecommons.org/licenses/BY/4.0), which permits unrestricted use, distribution, and reproduction in any medium, provided the original work is properly cited. 
The infection increases the hospital stay, mortality and the overall cost of health care ${ }^{1,7,8}$. Therefore, this study was aimed to find out the infection rate and pattern among orthopedic surgery patients in a tertiary care hospital with a view to develop an interventional program to reduce the incidence of such infections. Though all the hospitalized patients have a risk to acquire the infection, orthopedic patients have a greater risk due to prolonged hospitalization, nature of surgeries, open wounds and implants.

\section{Methods}

This study was conducted in an orthopedic unit of a tertiary care hospital, in South India. The hospital has more than 2032 beds with 150 beds for department of orthopedics. The data was collected from medical records of orthopedic surgery patients for one year in this retrospective observational study. After obtaining permission from institutional ethical committee, medical records of all the orthopedic patients, who underwent both elective and emergency orthopedic surgery were reviewed. Medical records of patients with compromised immunity status (HIV/AIDS, on immunosuppression therapy such as post-transplant patients) were excluded. Patients who required a bacterial culture test for a suspected or an obvious infection in the wound were included. The asymptomatic carrier state was not investigated. The wound swabs or tissue were collected during the surgery or in the post-operative period. The swabs were sent to microbiology department immediately for bacterial culture and sensitivity testing. The culture and antibiotic sensitivity testing was done by standard recommended method'.

In one year, 4,382 orthopedic surgeries were performed. A total of 2,282 patients had undergone major orthopedic surgeries and 2,249 patients were eligible as per the inclusion criteria. The surgeries included in the study were major wound debridement, implant and prosthesis insertion, joint replacement surgeries, major graft / flap reconstructions, and spinal surgeries. The data was collected using the proforma which consisted of age, gender, presence of open wound at the time of admission, location of injury, type of surgery and date of the surgery, pathogen grown in the culture test and date of the culture tested were included in the proforma. Two investigators independently collected the data. The reliability of the data collection was assessed by inter-rater reliability and found reliable (97\%).

\section{Results}

A total of 725 orthopedic surgery patients were found to be infected during the study period. The mean age of the patients was $40.3 \pm 17.3$ years and $83.7 \%$ were males. Nearly half $(49.1 \%)$ of the patients had open wounds during admission. The patients had injuries at different areas and the details are given in figure 1.

All patients $(100 \%)$ had surgery done once, $31.9 \%$ twice and $9 \%$ had three surgeries done (table 1$)$. The most of common surgical procedure performed was wound debridement (table 1). 


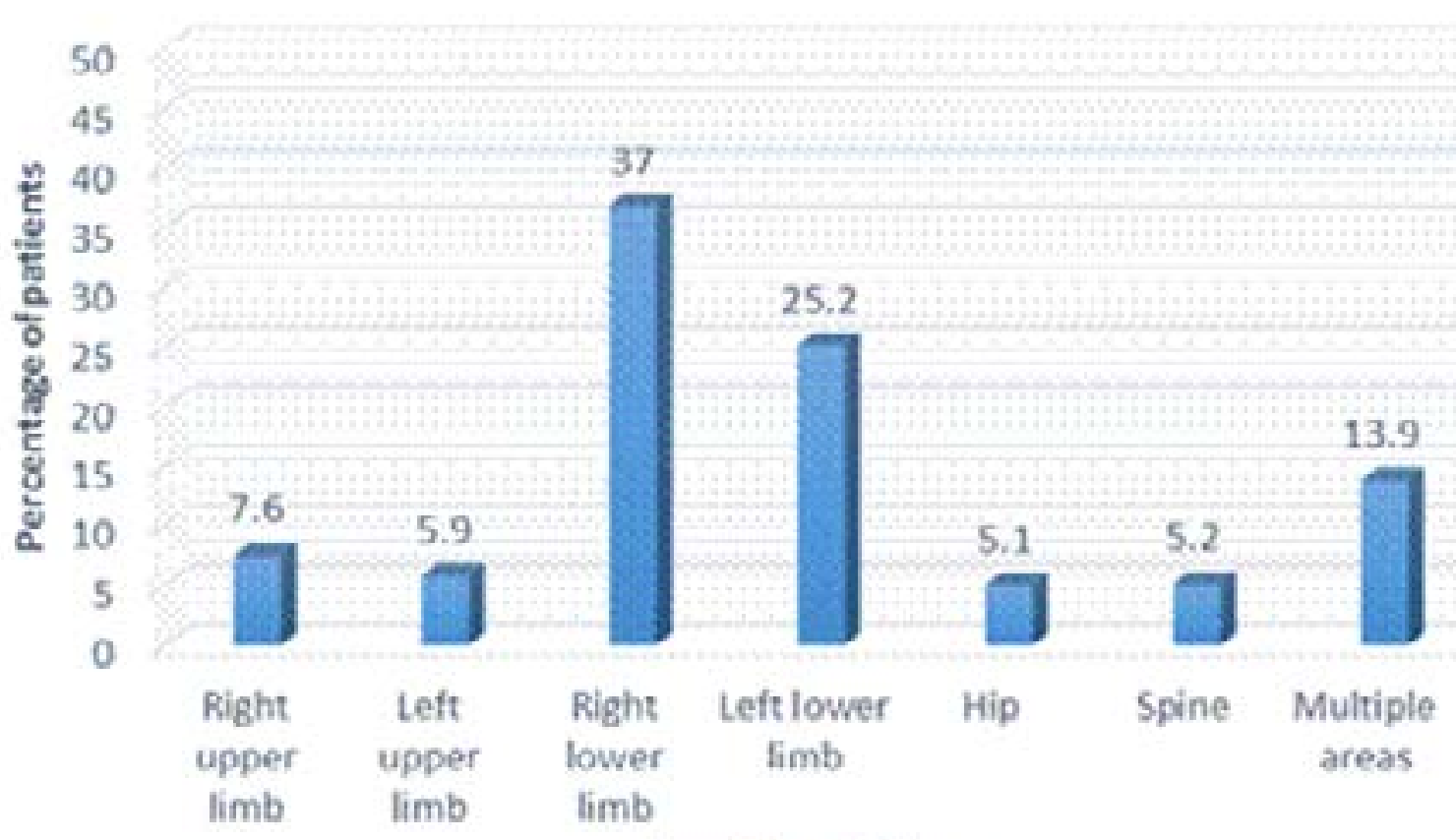

Location of injury

Fig 1: Location of injury among orthopedic surgery patients (total patients 725)

Table 1: The type of surgery among orthopedic surgery patients

\begin{tabular}{|l|l|l|l||l|l|l|}
\hline \multirow{2}{*}{ Name of the surgery } & \multicolumn{2}{l}{$\begin{array}{l}\text { First time } \\
\text { surgery }\end{array}$} & \multicolumn{2}{l|l}{$\begin{array}{l}\text { Second } \\
\text { surgery }\end{array}$} & \multicolumn{2}{l|}{$\begin{array}{l}\text { Third time } \\
\text { surgery }\end{array}$} \\
\cline { 2 - 7 } & $\mathrm{f}$ & $\%$ & $\mathrm{f}$ & $\%$ & $\mathrm{f}$ & $\%$ \\
\hline Wound debridement & 235 & 32.4 & 64 & 8.8 & 11 & 1.5 \\
\hline Flap reconstruction/ division & 13 & 1.8 & 8 & 1.1 & 6 & 0.8 \\
\hline External Fixator application & 24 & 3.3 & 5 & 0.7 & - & - \\
\hline Implant removal & 107 & 14.8 & 15 & 2.1 & 3 & 0.4 \\
\hline Split skin graft & 7 & 1.0 & 24 & 3.3 & 11 & 1.5 \\
\hline Implant insertion & 80 & 11.0 & 38 & 5.2 & 7 & 1.0 \\
\hline Replacement (Knee, Hip) & 35 & 4.8 & - & - & - & - \\
\hline Bone graft & 16 & 2.2 & 5 & 0.7 & - & - \\
\hline Incision and Drainage & 14 & 1.9 & 2 & 0.3 & - & - \\
\hline Spine Surgeries & 17 & 2.3 & - & - & - & - \\
\hline Exploratory Biopsy & 9 & 1.2 & - & - & - & - \\
\hline Amputation & 12 & 1.7 & 3 & 0.4 & 1 & 0.1 \\
\hline $\begin{array}{l}\text { Osteotomy, } \\
\text { debridement, corticotomy }\end{array}$ & 15 & 2.1 & - & - & - & - \\
\hline Multiple surgeries & 141 & 19.4 & 67 & 9.2 & 26 & 3.6 \\
\hline Total & 725 & 100 & 231 & 31.9 & 65 & 9.0 \\
\hline
\end{tabular}

$\mathrm{f}=$ frequency 
Bacterial culture testing report of 725 (32.2\%) specimens showed a growth of 946 micro-organisms among 2249 eligible orthopedic surgery patients. Some patients re- vealed the presence of monomicrobial and some patients had polymicrobial growth in their bacterial culture testing, making a total of 946 isolates (table 2).

\section{Table 2: The rate of Gram positive and Gram negative microbes among orthopedic surgery patients $n=725$ patients}

\begin{tabular}{|c|c|c|}
\hline & Frequency & Percentage \\
\hline \multicolumn{3}{|c|}{ Gram positive Micro-organism (Total 382 Organisms) } \\
\hline Staphylococcus Aureus & 351 & 48.4 \\
\hline$\bullet \quad$ MRSA & 201 & 27.7 \\
\hline$\bullet$ MSSA & 150 & 20.7 \\
\hline Enterococcus species & 31 & 4.3 \\
\hline \multicolumn{3}{|c|}{ Gram negative Micro-organism (Total 564 organisms) } \\
\hline Ecoli & 121 & 16.7 \\
\hline Proteus vulgaris & 18 & 2.5 \\
\hline Acinetobacter & 63 & 8.7 \\
\hline Pseudomonasaeruginosa & 191 & 26.3 \\
\hline Klebsiella pneumonia & 106 & 14.6 \\
\hline Enterobacter species & 29 & 4 \\
\hline Proteus mirabilis & 11 & 1.5 \\
\hline Klebsiella oxytoca & 10 & 1.4 \\
\hline Citrobacter species & 15 & 2.1 \\
\hline
\end{tabular}

Note: Polymicrobial growth was seen in some sample and a total growth of organisms was 946 among 725 patients.

Staphylococcus aureus was seen among 351 isolates, amounting to $48.4 \%$ compared to the other organisms. Among the 351 Staphylococcus aureus, 201 (57.3\%) were MRSA and $150(42.7 \%)$ were Methicillin sensitive Staphylococcus aureus (MSSA).

The calculated rate of infection among orthopedic surgery patient shows that MRSA was the leading cause of infection (27.7\%), followed by Pseudomonas aeruginosa $(26.3 \%)$ and MSSA (20.7\%). The infection rate during the study was $32.2 \%(725 / 2249)$.

The pattern of infection observed over one year period shows no uniformity. The monthly distribution of infection was suggestive that it was higher during June, July and August and significantly less in December and January (table 3). 
Table 3: Monthly distribution of microbes among orthopedic surgery patients $\quad n=946$

\begin{tabular}{|c|c|c|c|c|c|c|c|c|c|c|c|c|c|}
\hline $\begin{array}{c}\text { Month } \\
(2012-2013)\end{array}$ & E coli & $\begin{array}{l}\text { Proteus } \\
\text { vulgaris }\end{array}$ & $\begin{array}{c}\text { Acinetobacte } \\
r \text { species }\end{array}$ & $\begin{array}{c}\text { Pseudomonas } \\
\text { aeruginosa }\end{array}$ & MSSA & MRSA & $\begin{array}{c}\text { Klebsiella } \\
\text { pneumonia }\end{array}$ & $\begin{array}{c}\text { Enterobacter } \\
\text { species }\end{array}$ & $\begin{array}{l}\text { Citrobacter } \\
\text { species }\end{array}$ & $\begin{array}{c}\text { Enterococcus } \\
\text { species }\end{array}$ & $\begin{array}{l}\text { Proteus } \\
\text { mirabilis }\end{array}$ & $\begin{array}{c}\text { Klebsiella } \\
\text { oxytoca }\end{array}$ & Total \\
\hline June & 25 & 1 & 3 & 21 & 24 & 21 & 9 & 9 & 1 & - & - & - & 114 \\
\hline July & 14 & 3 & 4 & 14 & 12 & 34 & 10 & - & 3 & 1 & - & - & 95 \\
\hline August & 16 & - & 2 & 29 & 19 & 18 & 13 & 6 & 2 & 1 & 3 & 1 & 110 \\
\hline September & 5 & 4 & 6 & 15 & 12 & 9 & 9 & 2 & - & - & - & - & 62 \\
\hline October & 8 & 3 & 3 & 17 & 10 & 8 & 9 & 3 & 1 & - & 3 & 2 & 67 \\
\hline November & 6 & 3 & 5 & 16 & 16 & 9 & 8 & 1 & 2 & 1 & 1 & 1 & 69 \\
\hline December & 6 & 3 & 3 & 7 & 9 & 21 & 1 & 4 & 1 & - & - & 1 & 56 \\
\hline January & 5 & - & 5 & 13 & 8 & 18 & 5 & - & - & 4 & - & 1 & 59 \\
\hline February & 6 & 1 & 6 & 15 & 10 & 17 & 8 & 1 & 2 & 8 & - & - & 74 \\
\hline March & 9 & - & 6 & 17 & 12 & 15 & 13 & - & 1 & 7 & 2 & 2 & 84 \\
\hline April & 9 & - & 9 & 18 & 11 & 14 & 11 & 2 & 1 & 7 & 1 & - & 83 \\
\hline May & 12 & - & 11 & 9 & 7 & 17 & 10 & 1 & 1 & 2 & 1 & 2 & 73 \\
\hline Total & 121 & 18 & 63 & 191 & 150 & 201 & 106 & 29 & 15 & 31 & 11 & 10 & 946 \\
\hline
\end{tabular}

\section{Discussion}

The infection among orthopedic patients is very common. In the present study, the infection was higher among males (83.7\%). A similar result, $72.3 \%{ }^{11}, 75.5 \%{ }^{12}$, $81.4 \%{ }^{13}$ of infection among males is seen in previous reports. The mean age of the present study population was $40.3+17.3$ years which is in par with the earlier study showing the maximum infection in the age group of 31 40 years $^{12}$. Motor vehicles and road traffic accidents, fall from height and certain risk taking behaviors are more common among men could be the cause of the high prevalence of infection among them.

Infection of the leg and foot was $81.6 \%{ }^{12}, 64 \%{ }^{4}$ and the upper limbs $12.1 \%{ }^{12}$. In consensus with the prior studies, this study found that the location of injury was more in lower limbs (right lower - 37\% and left lower - 27.2\%). Possibly lower limbs, especially right side, is more prone to get injured as most of the people are right side dominant. Also the Indian vehicles have the driving seat on the right hand side which also could explain the reason for the predominance of the injury on the right side.
Wound infection results in increased morbidity and healthcare cost $\mathrm{t}^{1,7,8}$. Developing infection in the hospital is one of the adverse events. Staphylococcus aureus infection, $48.4 \%(351 / 725)$ is the major threat for orthopedic patients. The results are concurrent with the studies worldwide (table 4). The rate of orthopedic surgical site infection however, differed from hospital to hospital ranging from $12 \%{ }^{15}$ to $40 \%{ }^{5}$. Nevertheless, the much higher infection rate of $68 \%$ of infection is published among orthopedic patients in general and Pseudomonas aeruginosa 18 $(26.4 \%)$ was the predominant isolate followed by Staphylococcus aureus $17(25 \%)^{6}$.

The presence of MRSA (27.7\%) among orthopedic surgery patient is alarmingly high in the present study. This study also noted that among the Staphylococcus aureus infections, more than half of (57\%) was methicillin resistant. Table 4 summarizes the rate of infection from different studies. Added to that, Jain and Banerjee has observed $39.6 \%(21 / 53)$ Staphylococcus aureus as the most prevalent infection at surgical site among orthopedic surgery patients ${ }^{17}$. 
Table 4: Rate of orthopedic infections in the previous studies

\begin{tabular}{|c|c|c|c|c|c|c|c|c|c|c|c|}
\hline & Sample & $\begin{array}{l}\text { Staphylococcus } \\
\text { Aureus }\end{array}$ & $\begin{array}{l}\text { Enterococcus } \\
\text { species }\end{array}$ & E coli & $\begin{array}{l}\text { Proteus } \\
\text { vulgaris }\end{array}$ & Acinetobacter & $\begin{array}{l}\text { Pseudomonas } \\
\text { aeruginosa }\end{array}$ & $\begin{array}{l}\text { Klebsiella } \\
\text { pneumoniae }\end{array}$ & $\begin{array}{l}\text { Enterobacter } \\
\text { species }\end{array}$ & $\begin{array}{l}\text { Klebsiella } \\
\text { oxytoca }\end{array}$ & $\begin{array}{l}\text { Citrobacter } \\
\text { species }\end{array}$ \\
\hline $\begin{array}{l}\text { Present } \\
\text { study }\end{array}$ & $\begin{array}{l}\text { Wound/ tissue } \\
\text { of all major } \\
\text { orthopedic } \\
\text { surgery patients } \\
\text { with } \geq 18 \text { years } \\
\text { ( } 725 \text { patients) }\end{array}$ & 37 & 3.3 & 12.7 & 1.9 & 6.6 & 20.1 & 11.1 & 3.1 & 1.1 & 1.6 \\
\hline $\begin{array}{l}\text { Agrawal } \\
\text { et.al, } \\
2008^{5}\end{array}$ & $\begin{array}{l}\text { Fracture, } \\
\text { bedsore, wound } \\
\text { of all } \\
\text { orthopedic } \\
\text { patients (Jan } \\
\text { 2003-March } \\
\text { 2004) } \\
\end{array}$ & 18.9 & NA & NA & 6.31 & NA & 26.13 & 8.11 & NA & 8.11 & NA \\
\hline $\begin{array}{l}\text { Dhawan } \\
\text { et al., } \\
2005^{4}\end{array}$ & $\begin{array}{l}\text { Wound swab of } \\
\text { ortho patients - } \\
\text { hospitalized } \\
\text { (Jan 2000-June } \\
\text { 2003) } \\
\end{array}$ & 40 & 4 & 11 & 1 & 12 & 12 & 8 & 2 & NA & NA \\
\hline $\begin{array}{l}\text { Al- } \\
\text { Mulhim } \\
\text { et. al., } \\
2014^{19}\end{array}$ & $\begin{array}{l}\text { Wounds swabs } \\
\text { of hospitalized } \\
\text { orthopedic } \\
\text { surgery patients }\end{array}$ & 29.1 & 17.7 & 3.8 & NA & 21.5 & 19 & 3.8 & NA & NA & NA \\
\hline $\begin{array}{l}\text { Dash } \\
\text { et.al., } \\
2016^{20}\end{array}$ & $\begin{array}{l}\text { Wound swab } \\
\text { from compound } \\
\text { fractures and } \\
\text { post-operative } \\
\text { orthopedic } \\
\text { patients }\end{array}$ & 26.9 & 4 & 1.8 & 3.4 & 8.8 & 11.4 & 10.8 & NA & NA & 5 \\
\hline $\begin{array}{l}\text { Chandrash } \\
\text { ekar, } \\
2016^{12}\end{array}$ & $\begin{array}{l}\text { Wound swabs } \\
\text { of hospitalized } \\
\text { orthopedic } \\
\text { patients }\end{array}$ & 48.7 & NA & 22 & 3.3 & 3.3. & 25.4 & 15.3 & 22 & NA & 8.4 \\
\hline $\begin{array}{l}\text { Agaja, } \\
2008^{15}\end{array}$ & $\begin{array}{l}\text { Patients with } \\
\text { osteomyelitis } \\
\text { underwent } \\
\text { surgery }\end{array}$ & 37.6 & NA & 9.3 & 6.5 & NA & 6.5 & 9.3 & NA & NA & NA \\
\hline $\begin{array}{l}\text { Muley, L., } \\
2015^{21}\end{array}$ & $\begin{array}{l}\text { Hospitalized } \\
\text { orthopedic } \\
\text { patients }\end{array}$ & 40.9 & 12 & 15.9 & 2.3 & NA & 13.6 & 7.9 & NA & 2.3 & NA \\
\hline $\begin{array}{l}\text { Das, } \\
2015^{16}\end{array}$ & $\begin{array}{l}\text { Orthopedic } \\
\text { surgical site } \\
\text { infection }\end{array}$ & 24.8 & NA & 18.9 & 5.4 & 2.7 & 18.9 & 8.1 & 8.1 & NA & NA \\
\hline
\end{tabular}

NA: Not Available

A report conveyed that $53 \%$ Gram positive and $47 \%$ Gram negative infections were observed among orthopedic in-patients ${ }^{4}$, whereas another study says $51.3 \%$ infection was Gram negative ${ }^{12}$. In addition to this, a study has estimated $56.1 \%$ of Gram positive and $43.9 \%$ Gram negative bacilli infection ${ }^{11}$. The present study shows $40.6 \%$ Gram positive and 59.4\% Gram negative microbes.

The present study has seen $57.3 \%$ of Staphylococcus aureus as MRSA. The rate of MRSA is dissimilar between the hospitals ranging from $12 \% 0^{20}, 23.5 \%^{18}, 50 \% 0^{12}$, to $63 \%^{3}$. A study has reported $800(38 \%)$ positive cultures and Staphylococcus aureus (32\%) was the most common pathogen causing surgical site infection. MRSA was isolated in 44\% of Staphylococcus aureus infections. But, the rate of MRSA was not similar in different surgical specialty such as neurosurgery $(26 \%)$, orthopedics $(24 \%)$, pediatric $(17.8 \%)$, cardiothoracic $(14 \%)$, and general surgery $(7.1 \%)^{21}$. In a four year study on the prevalence of MRSA infec- tion among both out-patient and in-patient department, $38.44 \%$ MRSA infection was documented ${ }^{22}$.

One of the causes for higher rate of infection is performing emergency surgeries ${ }^{18}$. The present study has noticed that many patients were admitted from the trauma center and have undergone emergency surgeries. Usually, emergency surgeries are not well prepared like elective surgeries. Patients with an open fracture tend to be infected more $(14.7 \%)$ than a closed fracture $(4.2 \%)^{9}$. Having an open wound at the time of admission increases the risk of infection. Patients with open fracture and fracture fixation have a high rate of infection ${ }^{23}$. Possibly open wounds $(49.1 \%)$ were one of the causes of high infection rate among our patients. Also, repeated surgeries are common among orthopedic patients. many a times, wound debridement is performed as an emergency procedure for severe traumatic wounds. Later, the implant is used for internal fixation of fracture. Covering the wound with 
skin graft or flap is also a frequently performed surgery. Therefore, repeated exposure of orthopedic patients to operation room is unavoidable.

The growth of polymicrobial in an orthopedic wound is not uncommon ${ }^{18}$. Open fractures have a high risk of polymicrobial growth $(5.8 \%)$ due to exposure of the wounds and contamination than that of closed fracture $(1 \%)^{10}$ and many of our patients had polymicrobial infections; i.e. 946 microbes were grown from 725 patients.

We have observed that the infection rate was higher in the months of June, July and August and relatively lesser during December and January. In the months of June, July and August it is rainy season and December and January is winter in the present study setting. However, we could not trace any literature in relation to seasonal variation of bacterial infection among orthopedic surgery patients.

The wound swab was sent either during or after the surgery and the data was collected from the records. The investigators, therefore, were unable to differentiate community acquired infection and hospital acquired infection. Initial screening of pre-operative patients is not a routine practice in this study setting. We lacked data on antibiotic/s usage among the study population. Hence, additional research is needed to determine the rate of community acquired and hospital acquired infection and the causes of higher infection rate among the orthopedic cohort.

GARP - India working group has reported that the unreasonable use of antibiotic is the major threat for increasing multidrug resistant organism. In India, the abuse of antibiotics is not a new concept. Irrational or inappropriate prescription such as incorrect dose, frequency or duration; redundant or not considering the adverse interaction or reaction with other medications are observed in many parts of India. Prescribing the excess or unnecessary antibiotics has been documented in public and private hospitals, clinics and pharmacies ${ }^{24}$. The studies also have explored the antibiotic usage for simple viral problems such as upper respiratory infection, diarrhea, etc. ${ }^{25,26}$.

Certainly, these factors will increase the burden of the antibiotic resistant pathogen. The antibiotics are sold in many pharmacies without a proper prescription. In some places, it is available in general stores as well. The current study has been carried out in a tertiary care referral hospital. Hence, the usage of antibiotics by the primary physician or in the local hospital cannot be denied. Often, many orthopedic patients visit or get admitted to the hospital and undergo invasive procedures such as implant insertion or implant removal. Thus, the risk of MRSA increases among orthopedic surgery patients.

Coia et al. have given a systematically prepared guideline for prevention of MRSA infection ${ }^{27}$. The guideline explains about the different measures to be instigated in a hospital setting and feasibility of adopting this guideline in our setting need to be explored. However, executing a self-prepared guideline would give a better control of infection compared to adopting the guidelines from developed countries, as there are differences in hospital setting, resource availability and utilization, acceptance by the employees, practicability in implementing the measures and the causes of infection.

This study was conducted to develop an interventional program to reduce the infection rate. There are multiple interventions that have tried to decrease MRSA infection such as hand hygiene, nasal decolonization, pre-operative screening, isolation, cohort/barrier nursing, floor and environmental cleaning, etc. Unfortunately, no single intervention is found to be effective in reducing MRSA infection rate. Therefore, we have planned an intervention to find out the effectiveness of Extended Infection Control Measures (EICM) to reduce MRSA infection among orthopedic surgery patients. EICM includes routine infection control policies of the hospital along with other interventions such as pre-operative screening, treating high risk patients, isolation, education and frequent reinforcement of infection control ensures to health care providers, screening of healthcare providers to identify and treat carrier status.

\section{Conclusion}

Infection among the orthopedic surgery patients can have devastating consequences and hence newer measures are needed to combat this. Many hospitals in India have infection control committees which are working very hard to bring down the infection rates. Yet, the infection rate in several hospitals is high. The current study shows a 
high rate of MRSA infection. Often, traumatic injury patients are encountered with contaminated wounds and if not treated immediately, may end up with wound infection. Further, these patients may receive an improper or no first aid after the traumatic injury. Moreover, they may require emergency surgery and very little time is available for patient preparation. Some of the orthopedic patients undergo repeated surgeries such as debridement, skin or bone grafting, instrumentation and removal, open reduction and internal fixations etc. Hence, frequent hospitalization or visit to an out-patient department is directly proportional to the rate of infection. Though we cannot avoid some of these events, we certainly can reduce the infection rates in the present setting.

\section{Acknowledgement}

We acknowledge the staffs of Medical Record Department (MRD) for providing us the necessary files for smooth data collection process.

\section{References}

1. World Health Organisation. Health care-associated infections Fact sheet. World Heal Organisation [cited 2016 November 22]. 2015;4. Available from: http://www.who. int/gpsc/country_work/gpsc_ccisc_fact_sheet_en.pdf

2. Hospital-acquired infections high in India. 22 September 2011. [cited 2017 January 21]. Avaialable from: http://www.indiamedicaltimes.com/2011/09/22/hospital-acquired-infections-high-in-india-study/India Medical Times.

3. Patted SM, Chinagudi S, Soragavi VR, Bhavi SB. The prevalence of MRSA infection in orthopaedic surgery in a Medical College Hospital : A 2-year analysis. Biomed ResIndia. 2013;24(1):33-5.

4. Dhawan B, Mohanty S, Das BK, Kapil A. Bacteriology of orthopaedic wound infections in an Indian Tertiary Care Hospital. Indian J Med Res. 2005 April;121:784-5.

5. Agrawal AC, Jain S, Jain RK, Raza HKT. Pathogenic bacteria in an orthopaedic hospital in India. I Infect Developing Countries. 2008;2(2):120-3.

6. Mathur P, et al. Implementation of a short course of prophylactic antibiotic treatment for prevention of postoperative infections in clean orthopaedic surgeries. Indian J Med Res. 2013 January;137(1):111-6.

7. Zimlichman E, Henderson D, Tamir O, Franz C. Health Care-Associated Infections A Meta-analysis of
Costs and Financial Impact on the US Health Care System. JAMA Intern Med. 2013;173(22):2039-46.

8. Yalcin AN. Socioeconomic burden nosocomial of nosocomial infections. Ind J Med Sci. 2003;57(10):6-9.

9. O'Leary WM. Practical Handbook of Microbiology [Internet]. Practical Handbook of Microbiology 1989;10911. [cited 2017 January 15] Available from: http://books. google.com/books?hl=de\&lr=\&id=erL29sLL5nEC\&pgis $=1$

10. Oliveira PR, Carvalho VC, da Silva Felix C, de Paula AP, Santos-Silva J, Lima ALLM. Incidence and microbiological profile of surgical site infections following internal fixation of closed and open fractures. Rev Bras Ortop. 2016;51(4): 396-9.

11. Naik TB, Wadekar MD, Upadhya A, Mane V. Cross sectional analysis of aerobic bacteria and their antibiotic susceptibility pattern among orthopedic wound infections at a tertiary care hospital in Karnataka. Indian J Microbiol Res. 2016;3(1):58. Available from: http://www.indianjournals.com/ijor.aspx?target=ijor:ijmr1\&volume=3\&issue $=1$ \&article $=015$

12. Chandrashekhara B, Sangeetha S. Isolation Identification and its Drug Susceptibility Pattern in Orthopaedic Wound Infections. Int J Curr Microbiol App Sci. 2016;5(9):213-8.

13. Akinkunmi EO, Adesunkanmi AR, Lamikanra A. Pattern of pathogens from surgical wound infections in a Nigerian hospital and their antimicrobial susceptibility profiles. Afr Health Sci. 2014;14(4):802-9.

14. Agaja SB, Ayorinde RO. Chronic osteomyelitis in Ilorin, Nigeria. S Afr J Surg. 2008;46(4):116-8.

15. Das R, Singh A, Srivastava P, Pradhan S, Murthy R. Microbial Profile and Antibiotic Susceptibility Pattern of Surgical Site Infections in Orthopedic Patients at a Tertiary Hospital in Bilaspur. International Journal of Scientific Study. 2015 June;3(3):43-7.

16. Devi PV, Reddy S, Shabnum M. Microbial profile and antibiotic susceptibility pattern of orthopedic infections in a tertiary care hospital: A study from South India. Int J Med Sci Public Heal. 2017;6(4):1-4.

17. Jain B, Banerjee M. Surgical site infections and its risk factors in orthopaedics: a prospective study in teaching hospital of central India. Injury. 2013;2(1):110-3.

18. Al-Mulhim FA, Baragbah MA, Sadat-Ali M, Alomran AS, Azam MQ. Prevalence of surgical site infection in orthopedic surgery: A 5-year analysis. Int Surg. 2014;99(3):264-8. 
19. Dash A, et al. Surveillance of antibiotic sensitivity and resistance pattern of bacteria isolated from orthopaedic wound discharge. Int J Pharm Sci Rev Res. 2016;36(1):20811.

20. Muley VA, Ghadage DP, Bhore A V. Bacteriological Profile of Neonatal Septicemia in a Tertiary Care Hospital from Western India. J Glob Infect Dis. 2015;7(6):75-7. 21. Tyagi A, Kapil A, Singh P. Incidence of Methicillin resistant Stabylococcus aureus (MRSA) in pus samples at a tertiary care hospital, AIIMS, New Delhi. Journal, Indian Acad Clin Med. 2008;9(1):33-5.

22. Tiwari HK, Sapkota D, Sen MR. High prevalence of multidrug-resistant MRSA in a tertiary care hospital of northern India. Infect Drug Resist. 2008;1:57-61. PubMed. 23. Willey M, Karam M. Impact of Infection on Fracture Fixation. Orthop Clin North Am. Orthop Clin N Am. 47 (2016) 357-4.
24. Global Antibiotic Resistance Partnership-India (GARP-India). Situation Analysis: antibiotic Use and Resistance in India. 2011;(March):1-83.

25. Sharma M, Eriksson B, Marrone G, Dhaneria S, Stålsby Lundborg C. Antibiotic prescribing in two private sector hospitals; one teaching and one non-teaching: A cross-sectional study in Ujjain, India. BMC Infect Dis. 2012;12(155):1-9. PubMed.

26. Kotwani A, Holloway K. Antibiotic prescribing practice for acute, uncomplicated respiratory tract infections in primary care settings in New Delhi, India. Trop Med Int Health. 2014;19(7):761-8.

27. Coia JE, et al. Guidelines for the control and prevention of meticillin-resistant Staphylococcus aureus (MRSA) in healthcare facilities. J Hosp Infect. 2006;63(sup 1):144. 